\title{
Myths, Misconceptions and Myopia: Searching for Clarity in the Debate about the Regulation of Consumer Genetics
}

\author{
S. Hogarth \\ Global Biopolitics Research Group, King's College London, London, UK
}

\author{
Key Words \\ Consumer - Direct-to-consumer - Genetic testing $\cdot$ Personal \\ genomes $\cdot$ Regulation
}

\begin{abstract}
The new wave of companies offering genome scans directto-consumer (DTC) has prompted commentary from scientists, clinicians, bioethicists and those interested in the ethical, legal and social issues arising from genomics. It has thus brought a far wider range of actors into a longstanding debate about the regulation of genetic tests. However, some of the recent discussion is characterised by misunderstanding of the regulatory landscape, a failure to grasp the lessons of the past and lack of clarity of thought. In this commentary I challenge a series of myths and misconceptions which plague current academic and policy discussion: the conflation of regulation and proscription; the failure to recognise that DTC companies are gatekeepers; the assumption that requiring a medical intermediary for testing is paternalistic; the belief that online services cannot be regulated; the presumption that we must avoid genetic exceptionalism; the idea that policy is lagging behind science or that it is too soon to act; and finally, the view that DTC genetics is a reality we have to adapt to.

Copyright $\odot 2010$ S. Karger AG, Basel
\end{abstract}

\section{KARGER}

Fax +41613061234

E-Mail karger@karger.ch

www.karger.com (c) 2010 S. Karger AG, Basel

Accessible online at: www.karger.com/phg

\section{Introduction}

A new wave of companies are offering genome scans for a range of single nucleotide polymorphisms (SNPs) related to common diseases direct to customers. This has prompted commentary from scientists, clinicians, bioethicists and ethical, legal and social issues scholars. The utility of testing, the vulnerability of the public to misleading claims and the appropriateness of marketing tests direct-to-consumer (DTC) are just some of the issues which have been raised. This commentary has brought a far wider range of actors into what has been a longstanding debate about the regulation of genetic tests. Greater attention focused on this issue is welcome and necessary, but some of the recent discussion is characterised by misunderstanding of the regulatory landscape, a failure to grasp the lessons of the past and lack of clarity of thought. We are in danger of being misguided by myths, misconceptions and myopia. In this commentary, I draw on several years of academic research and policy engagement in this area to challenge some of the current discourse.

\section{Myth Number 1: Regulation Means Proscription}

At meetings on this topic, one frequently hears statements which conflate regulation and proscription. Speakers imply, or even state explicitly, that to regulate a market 
such as consumer genetics is, in effect, to ban it. In fact, the opposite is often the case: just as a free market is underpinned by the state's willingness to enforce the law of contract, so many industries, from air travel to restaurants, are underpinned by a regulatory framework which ensures public safety and confidence.

So, if regulation is not proscription, then what is it? Regulatory theorists describe regulation as comprising 3 activities: information gathering (essential in order to understand and monitor the object of regulation), standard setting and behaviour modification (the enforcement of standards may involve incentives as well as penalties) [1].

\section{Myth Number 2: Requiring a Medical Consultation for a Genetic Test Infringes the Right of an Individual to Have Access to Their Genetic Data}

Underlying this idea is an imagined dichotomy between intrusive state meddling in the lives of citizens and a free market which respects individual liberty [2]. However, this assumes that it is only the state which can constrain freedom of choices and that the market is constituted by free and equal transactions between consumers and suppliers. In reality, markets may be characterised by gross inequities of power between wealthy corporations and individual consumers, not least the kind of profound asymmetries of information which make it difficult for the average consumer to judge the veracity of the scientific claims made by consumer genetics companies.

The asymmetrical nature of the relationship between consumer and company reminds us that the utopian dream of unmediated access to knowledge of our genomes is currently available to only a handful of scientists with the correct training and access to the necessary equipment (for data generation) and journal subscriptions (for data interpretation). Since the rest of us must rely on expert assistance, full and free access to our genomes is perhaps better described as a privilege rather than a right. Whether via a state healthcare system, a private clinic or a consumer genetics company, we access our genomic data through intermediaries who perform multiple gatekeeping functions. Consumer genetics companies control our access to our genomic data by setting standards on what they report, how they report it and who they report it to. Additional gatekeeping mechanisms include pricing (how much a service costs will determine who can access it) and efforts to keep competitors out of the market.
Once we accept that industry performs a gatekeeping role, it becomes clear that the policy dilemma we face is not a choice between medical paternalism, draconian state regulation and a free market in genomic data. It is about deciding who the gatekeepers are, what sort of controls are in place, who sets the standards, and how they are enforced. If we leave the gatekeeping role to the market then the capacity for standard setting is wholly privatised. It is at the very least questionable whether this will lead to optimum outcomes for the public.

\section{Myth Number 3: Banning DTC Genetic Testing Would Be Unduly Paternalistic}

A recent editorial in Personalized Medicine declares that consumer genetics 'undermines traditional professional paternalism' [3]. The view that such services are another nail in the coffin of professional medical hegemony seems very common. Underlying this perception are 2 assumptions: that in contemporary society, individuals increasingly engage in self-directed management of their physical and mental wellbeing, and that there has been a corresponding diminution in the role and authority of qualified healthcare professionals [4]. If we truly are in an era of post-paternalist healthcare, then indeed it might be unreasonable to require health consumers to access genetic tests through a physician, but have we reached this golden age? The argument for a more selfreliant consumerist public is questionable; we lack proper historical data that might clearly demonstrate significant change over time. Moreover, whilst there can be little doubt that the authority of the medical profession has faced repeated challenges in recent decades, in many respects, doctors' professional power and status are little diminished [5]. Indeed, much contemporary public and private dissatisfaction with doctors arises precisely because patients still rely on them so heavily for expert guidance and care.

Furthermore, regulatory policy governing pharmaceuticals has not moved into a post-paternalist era. There continues to be a mixed economy of provision, with some drugs available DTC in pharmacies but many others only available via a doctor's prescription. Indeed, prescription pharmaceuticals cannot even be advertised DTC in most countries, despite strong industry pressure for liberalisation. There seems to be no public desire for this mixed model to change. Fittingly, the most convincing refutation of the post-paternalist argument comes from the public itself. Repeated surveys have shown that the ma- 
jority of the public want the involvement of a medical professional when ordering a genetic test [6-8]. Perhaps, if consumer genomics companies truly believe in 'democratising' genomics, then they should respond to the wishes of the majority and provide the clinical support that the public desire. Certainly the model of pharmaceutical regulation would suggest that it is not unreasonable to envisage a regulatory environment where only certain categories of genetic tests are available DTC, and others are available solely via a physician.

\section{Myth Number 4: The Internet Has Created a Global Market beyond the Reach of Regulation}

Some suggest that even if regulation was desirable, it would be impractical. By selling their services on the internet, it might appear that consumer genetics companies have created a global trade in DNA analysis that cannot be regulated by individual nation states. In such a situation, perfect enforcement is indeed impossible, but then that it is a failure of most regulatory regimes. Regulators can nevertheless have a substantial impact on markets, even if they cannot prevent all violations of their rules. Some online industries have been subject to control by certain national governments, which have sought to exert regulatory authority in controversial areas such as online gambling [9].

Furthermore, the existence of anything approaching a global market is questionable. In my own research on consumer genetics, I have spoken to 2 US firms who stated that they have not attempted to enter the UK market in part because they mistakenly believed that DTC genetic testing was illegal there [10]. So even the perception of regulation has had an impact on the global reach of the market. Moreover, it is likely that the primary reason for some US companies not entering the UK market is that they lack the capacity to make any sustained effort at marketing in Europe. Consumer genetics companies are not giant transnational corporations; most are unlikely to possess sufficient financial capital to succeed in building a presence across multiple territories, and since most are US-based, it makes sense for them to concentrate on their national market. Thus it is far from clear that, even in purely commercial terms, DTC genetic testing is currently a truly borderless, global market. Finally, the actions of 2 US states - New York and California - in seeking to constrain consumer genetics companies by enforcing their statutory restrictions on DTC diagnostics services suggest that, far from this being a global market, it may not even be national [11].

\section{Myth Number 5: Policy Responses to DTC Genetics Must Avoid Genetic Exceptionalism}

The spectre of genetic exceptionalism has been raised as a danger in this policy discussion, with many commentators assuming that it is to be avoided [12]. Certainly, the arguments we are having are not unique to genetics; controversy has flared around DTC pregnancy tests and HIV tests in past decades. However, what is new (or exceptional) is the scale and pace of change. The problem is particularly acute in this field for a variety of reasons, the chief one being technological. It is now possible to go from a new research discovery straight to commercialisation: the SNPs are already on the chips. Couple this advantage with the new medium of internet delivery as a means to engage directly with the public, and you have the perfect storm for consumer diagnostics. It is in this regard, above all, that we are witnessing something truly novel in the diagnostics sector. The diagnostics industry has long had a consumer market, and a range of tests are available for purchase over the internet or in pharmacies, but never before have we had a situation where new biomarkers move from discovery to DTC provision with no intervening period of gradual adoption by the medical profession. This is an exceptional situation and it may require an exceptional policy response.

\section{Myth Number 6: It Is Too Soon to Act}

More than any of the other issues I have already outlined, it is here that we see evidence of myopia. The shortsightedness is particularly acute because the unobserved object is not that distant. A review of the last 15 years of policy debate on the regulation of genetic testing demonstrates that there are no new issues on the table [13]. The current debate largely revolves around 2 related but conceptually distinct controversies: the utility of genetic susceptibility testing and the potential dangers of DTC marketing of genetic tests. Neither is novel. The former dates back (at latest) to the controversy over APOE4 and Alzheimer in 1994 [14] and the latter to the launch of a DTC service for cystic fibrosis carrier testing in the UK in 1995 [15]. The first policy response came in 1997 with the launch in the UK of a code of practice [16]. Detailed policy analysis has followed since, most notably the Human Genetics Commission's 2003 Genes Direct report and their 2007 follow-up [17]. Successive reports in the US have analysed the cracks in the regulatory paving through which the first green shoots of consumer genetics have 
sprung. As far back as 2001, the Secretary's Advisory Committee on Genetic Testing had recommended a comprehensive plan of action not that different to last year's report by their successor committee [18].

Not only has previous policy work covered the relevant issues; it has even had the prescience to foresee the current situation. In 1997, the US Task Force on Genetic Testing warned that our capacity to respond to events would one day be outstripped by the rapid pace of commercialisation of new tests [19]. We have reached that point. Gone are the days when the discovery of a gene-disease association like APOE4 for Alzheimer would bring together clinicians, patient groups and scientists to produce a guideline warning against its clinical use. The same concerns are there, but, just as predicted, the pace of discovery and commercialisation has outstripped the responsive capacity of such ad hoc regulatory initiatives.

\section{Myth Number 7: Consumer Genetics Is a Reality We Have to Adapt to}

In a recent opinion piece, employees of personal genomics company 23 andme argued that consumer genetics was a train which had already left the station [20]. In this powerful metaphor of technological progress, the locomotive is an unstoppable force whose advance is inevitable because it travels on a track which has already been laid out. The reality is somewhat different. The truth is that consumer genetics companies are operating with business models which are entirely unproven [21]. Recent developments bear witness to the fragility of this space: the demise of Sciona (a pioneer in consumer genetics); the lay-offs at 23andme; the repositioning of DNA Direct as a company working with healthcare professionals; a similar shift by Navigenics; and finally, the bankruptcy of
deCODE and the apparent jeopardy of its consumer service under its new ownership [22]. All these demonstrate that the commercial viability of consumer genetics remains unproven. Further evidence to that fact is the decision by a number of companies in this space to eschew DTC testing, including the German firm GATC, the UK firm Genetic Health and the US firms InterGenetics and Celera.

\section{Conclusion}

Finally, in reviewing the current controversy about consumer genomics, we might ask whose interests are served by the choice of ideological terrain. Entering a debate which has been framed by the logic of the free market and the imperative of technological innovation at all costs, those who are sceptical about the value of consumer genetics are too often on the defensive, fearful of being tainted as outmoded paternalists attacking the rights of consumers or as Luddite technophobes. But rejection of useless technologies is the mark of the technophile, not the technophobe. Perhaps we need to move the debate onto new ground and recast this issue as a political one. The choices we make as citizens about the technologies we use can have profound implications for the nature of our society. Shaping the future of genetic testing may be something which is better done as a collective polity rather than as individual consumers.

\section{Acknowledgement}

The policy study informing this paper was funded by the Wellcome Trust bioethics programme, which played no part in the writing of this paper or the decision to submit it for publication.

\section{References}

1 Hood C, Rothstein H, Baldwin R: The Government of Risk - Understanding Risk Regulation Regimes. Oxford, Oxford University Press, 2001, pp 24-27.

2 Angrist M: Personal genomics: access denied? MIT Technology Review, September/ October 2008.

3 Mardis R, Lunshof J: A focus on personal genomics. Per Med 2009;6:603-606.

4 Williams S, Calnan M (eds): Modern Medicine: Lay Perspectives and Experiences. London, UCL Press, 1996, pp 8-13.
5 Salter B: The New Politics of Medicine. Basingstoke, Palgrave Macmillan, 2004.

6 McGuire A, Diaz C, Wang T, Hilsenbeck S: Social networkers' attitudes toward directto-consumer personal genome testing. Am J Bioeth 2009;9:1-2.

7 Reid R: Direct-To-Consumer Genetic Tests and Consumers presented at Direct-to-Consumer Genetic Testing: Ethical and Regulatory Issues. University of Oxford, May 2009.
8 YouGov Ltd: Public attitudes to genetic testing. A quantitative study for the Human Genetics Commission. London, YouGov, 2003.

$\checkmark 9$ Keller B: The game's the same: why gambling in cyberspace violates federal law. Yale Law J 1999;108:1593-1596.

10 Interviews with US DTC genetic testing industry executives: June 2007 and May 2008.

11 Langreth R, Herper M: States crack down on online gene tests. Forbes Magazine, April 18, 2008. 
12 PHG Foundation: Consultation Response Medical Profiling and Online Medicine: The Ethics of 'Personalised' Healthcare in a Consumer Age. Available at http://www. phgfoundation.org/file/4720.

13 Hogarth S, Javitt G, Melzer D: The current landscape for direct-to-consumer genetic testing: legal, ethical, and policy issues. Annu Rev Genomics Hum Genet 2008;9: 161-182.

14 American College of Medical Genetics/ American Society of Human Genetics Working Group on ApoE and Alzheimer disease: statement on use of apolipoprotein E testing for Alzheimer disease. JAMA 1995;274: 1627-1629.
15 Hogarth S, Melzer D, Zimmern R: The Regulation of Commercial Genetic Testing Services in the UK. Cambridge, Cambridge University, 2005. Available at www.hgc. gov.uk/UploadDocs/DocPub/Document/ stuart_hogarth.doc.doc.

16 Advisory Committee on Genetic Testing: Third Annual Report and Compendium of Guidance. London, HMSO, 1999.

17 Human Genetics Commission: Genes Direct: ensuring the effective oversight of genetic tests supplied directly to the public. London: 2003 and Human Genetics Commission. More Genes Direct. London, 2007.

18 Secretary's Advisory Committee on Genetic Testing: Enhancing the Oversight of Genetic Tests: Recommendations of the SACGT. Bethesda, National Institutes of Health, 2000. Secretary's Advisory Committee on Genetics, Health and Society: U.S. system of oversight of genetic testing: a response to the charge of the Secretary of Health and $\mathrm{Hu}$ man Services. Bethesda, National Institutes of Health, 2008.
19 Task Force on Genetic Testing: Promoting Safe and Effective Genetic Testing in the United States. Bethesda, National Institutes of Health, 1997.

20 Hsu A, Mountain J, Wojcicki A, Avey L: A pragmatic consideration of ethical issues relating to personal genomics. Am J Bioeth 2009;9:3-10.

21 Martin P: Who wants personal genomics? The commercial development of DTC genetic testing and the problem of creating new markets for novel technologies. Presentation at The Age of Personalised Genomics, 5th International DNA Sampling Conference, Banff, 2009.

22 Carmichael M: The world's most expensive failure. Newsweek, February 22, 2010. 
